Original research article

\title{
Traditional birth attendants' labour pain management experiences from parturients care
}

\author{
Arunibebi L. Lawrence ${ }^{1 *}$, Agnes N. Anarado ${ }^{2}$, Chikaodili N. Ihudiebube-Splendor ${ }^{2}$ \\ ${ }^{1}$ Niger Delta University, Faculty of Nursing Sciences, Department of Community Health Nursing, Wilberforce Island, Bayelsa State, Nigeria \\ ${ }^{2}$ University of Nigeria, Faculty of Health Science and Technology, College of Medicine, Department of Nursing Sciences, Enugu, Nigeria
}

\begin{abstract}
Aim: The study explored Traditional Birth Attendants' (TBAs') perceptions of labour pain management experiences from parturients care in the Ogbia Local Government Area, Bayelsa State Nigeria.

Methods: The study adopted a phenomenological-hermeneutics research design. Using the purposive and snowball sampling techniques, 13 TBAs were recruited for this study. The data collection strategy was in-depth face-to-face interviews.

Results: Three major themes emerged: (1) TBAs' beliefs and attitude to labour pain, (2) TBAs' experiences of pain management during labour and (3) remedies provided to relieve labour pain and support to speed up childbirth.

Conclusions: Pain is a natural phenomenon but expressed differently from one parturient to another. TBAs' perception of labour pain is an indicator of how TBAs interpret and manage labour pain expressed by parturients. TBAs management approaches are more effective with the use of locally available remedies in form of herbs aimed at speeding up the delivery process.
\end{abstract}

Keywords: Labour pain management; Local remedies; Parturients; Perception; Traditional birth attendants

\section{Introduction}

Labour pain management remains an important challenge for midwives (Chaillet et al., 2014; Klomp et al., 2016) in all settings of practice (Gama et al., 2016); and is mainly associated with severe pain for most women. As such, most women report unsatisfactory childbirth experiences (Aksoy and Yucel, 2016; Halperin et al., 2014; Nilsson and Lundgren, 2009).

In Africa, traditional birth attendants (TBAs) are mostly known to provide maternal and infant health care services for the women; with practices geared towards benefits for health and well-being, including approaches (though some are harmful) that are culturally accepted such as: the use of locally prepared remedies and herbs (Saravanan et al., 2011). However, the perception of labour pain varies in different settings of practice, and among traditional midwives involved in assisting parturients (Gama et al., 2016). Thus the approach to labour pain management may also be relatively different, based on the parturient perception of labour pain, perception of the TBA, TBAs' expertise on the approach and/or availability of the local remedies (Aziato et al., 2016; Henderson et al., 2013; Klomp et al., 2016). There are also very different settings for childbirth, and the nature of the setting often dictates what is possible in terms of pain management. Many births take place at home where the use of pharmacological products for pain management may not be readily available (Christiaens et al., 2010; Hodnett et al., 2012).
In recent times, intervention to reduce pain during labour has been of great concern in modern obstetric midwifery with a wide array of pharmacological products and non-pharmacological approaches. Many other methods are adopted to manage labour pain; however, it is the responsibility of the midwife to choose the desired techniques in managing labour pain (Pirdel and Pirdel, 2009). Evidence revealed that the majority of women reported that the practice of companionship and back rubbing in labour helped parturients to cope better with the labour process. In contrast, there are well established theoretical reviews and empirical studies concerning labour pain management in clinical/orthodox settings, looking at the well-researched pharmaceutical products and non-pharmacological approaches that are made available for the management of labour pain (Aduloju, 2013). Some studies have shown that when women are offered analgesia during labour, they report greater satisfaction with their overall birth experience (Gama et al., 2016; Ogboli-Nwasor et al., 2011). Although a wide range of labour pain management methods and interventions are available, no single universal method of managing labour pain exist that fits all circumstances and meets all parturient needs (Jones et al., 2012).

Cultural and religious beliefs also colour the perception, sensitivity and interpretation of TBAs' experience of working with parturients and thus dictate how TBAs would respond to the parturients' expression during the period of labour, as well as the use of an acceptable choice on managing the pain during labour (Christiaens et al., 2010; Gallegos et al., 2017).

\footnotetext{
* Author for correspondence: Arunibebi L. Lawrence, Niger Delta University, Faculty of Nursing Sciences, Department of Community Health Nursing, Wilberforce Island, Bayelsa State, Nigeria; e-mail: lawrenceibebi@gmail.com http://doi.org/10.32725/kont.2020.008

Submitted: 2019-09-05 • Accepted: 2020-02-18 • Prepublished online: 2020-02-25

KONTAKT 22/1: 47-53 • EISSN 1804-7122 • ISSN 1212-4117

(c) 2020 The Authors. Published by University of South Bohemia in České Budějovice, Faculty of Health and Social Sciences.

This is an open access article under the CC BY-NC-ND license.
} 
Also, how TBAs respond to parturients' labour pain depends on factors such as cultural attitude to normalcy and conduct of birth. Expectations of how a woman should act in labour and the degree and quality of support from the birth attendant, influences TBAs' perception of care (Whitburn et al., 2014).

\section{Problem statement}

Two philosophical views exist as it relates to labour pain and how it should be managed (Aziao et al, 2016). Mostly based on trado-religious perspective; some birth attendants are of the view that parturients must go through the pain of labour and childbirth as a divine punishment for disobedience, hence nothing should be done to relieve the pain; whereas others are of the view that labour pain should be controlled (Klomp et al., 2016; Leap et al., 2010). Thus assisting women during labour and childbirth has been an important role in midwifery practice (Chaillet et al., 2014; Malheiros et al., 2012). Therefore, what philosophical view do TBAs in the Ogbia Local Government Area (LGA) in Bayelsa State hold and operate in terms of their perception of labour pain and management?

With the provision of primary health centers for delivery manned by trained midwives in Ogbia LGA, traditional practices of childbirth seem to be receiving increased patronage. However, while the trend of professional healthcare deliveries has yielded positive health outcomes, TBAs' management of labour pain still remains unclear and undocumented: still in all these uncertainty with the TBA process childbirth, rural women have been delivering with TBAs. Also, even with established evidence that some practices of TBAs are detrimental to parturients and unborn babies (Lawrence et al., 2015a, b; Saravanan et al., 2011), the researchers wonder what TBAs do in managing labour pains. In line with the above, this research explored TBAs' perceptions of labour pain management experiences from the care of Parturients in the Ogbia Local Government Area, Bayelsa State. This study addressed the following: what are the common beliefs about labour pain among TBAs and what are TBAs' experiences of pain management practices during labour?

\section{Materials and methods}

This was a qualitative study which adopted a phenomenological-hermeneutics research design to explore and interpret the TBA's perception of labour pain and its management experience among parturients. The study population comprised only TBAs residing in Ogbia LGA of Bayelsa State, Nigeria. The total population of TBAs in Ogbia LGA was unknown; as at the time of the study there was no record of their number from the Local Government health records.

Purposive and snowball sampling techniques were used to recruit a total of 13 TBAs who met the following inclusion criteria: participant must be a mother, have been a practicing TBA for more than five years, must have delivered an average of 20 parturients yearly and have experience in managing parturients, aged 40 years and above, and be able to consent for themselves. An unstructured interview guide with three major questions was used to guide the individual in-depth interview for data collection. This technique ensures that the researchers give participants freedom of expression to respond in their own words and provide as much detail as they wish. The interviews were tape recorded and transcribed verbatim with interviewees' permission.

Thematic analysis was used to analyse data. By using this approach, the digital audio-taped interviews were transcribed verbatim and checked for accuracy by reading the transcripts while listening to the audio-tapes. The validity and reliability of the study instrument was based on the four criteria as suggested by Lincoln and Guba (1985) as cited in Polit and Beck (2012) for developing the trustworthiness of a qualitative inquiry. Their suggestion includes: Credibility, Transferability, Dependability and Confirmability. An ethical approval for the study was obtained from Bayelsa State Ministry of Health Ethical Committee (BSMoHEC). Verbal informed consent was obtained from the participants after they were provided with information on the nature of the study.

\section{Results}

The results were presented in tables using themes and categories, which emerged from the transcriptions. Three (3) major themes emerged. In some situations, the same significant statement(s) were included in more than one category because a statement might represent two or more topics.

\begin{tabular}{lc}
\hline Table 1. TBA's demographic characteristics & \\
\hline Variable & Frequency $(f)$ \\
\hline Age & \\
$40-44$ & 1 \\
$45-49$ & 3 \\
$50-54$ & 6 \\
$55-59$ & 3 \\
\hline Marital status & \\
Married & 8 \\
Separated & 5 \\
\hline Educational level & \\
Primary & 3 \\
Secondary & 2 \\
Tertiary & 1 \\
None & 7 \\
\hline Religion & \\
Christianity & 11 \\
Traditionalist & 2 \\
\hline Occupation & \\
Civil servant & 3 \\
Farmer & 6 \\
Trader & 4 \\
\hline
\end{tabular}

The result showed the majority (6) of TBAs were in the age range of 50-54. 8 TBAs were married, while 5 TBAs were separated from their husbands and none were single. Only 3 TBAs had acquired primary school education, 2 TBAs had acquired secondary education, 1 TBA had acquired tertiary education. Also, the majority (11) of TBAs were Christians, while only 2 TBAs said their religious affiliation was traditional. The table also shows that in addition to $r$ practicing local midwifery; 3 TBAs said they were also civil servants, 4 TBAs said they were farmers, while 4 TBAs were traders.

\section{TBAs'beliefs and attitude to labour pain}

This theme showed evidence of TBAs' belief in the naturalness of labour pain, showing that labour pain is a normal and natural phenomenon. Most TBAs had this to say "... labour pain is a normal thing...", while other TBAs expressed that labour pain is divine and designed by God: "Labour pain is exactly what God said is going to happen when it comes to pregnancy and childbirth..." 


\begin{tabular}{lll}
\hline \multicolumn{2}{l}{ Table 2. Themes and categories that emerged } \\
\hline \multicolumn{2}{|c}{ Themes } & Categories \\
\hline \multirow{2}{*}{$\begin{array}{l}\text { TBAs' beliefs and } \\
\text { attitude to labour pain }\end{array}$} & $\begin{array}{l}\text { Naturalness of labour pain } \\
\text { A necessity for a woman to have } \\
\text { children }\end{array}$ \\
\hline & Evaluation of parturients labour pain \\
& $\begin{array}{l}\text { TBAs' experiences } \\
\text { of pain management } \\
\text { during labour }\end{array}$ & $\begin{array}{l}\text { Psychological support } \\
\text { Preferred setting for comfort in } \\
\text { conducting delivery }\end{array}$ \\
\hline \multirow{2}{*}{$\begin{array}{l}\text { Remedies provided to } \\
\text { relieve labour pain and } \\
\text { support to fasten child } \\
\text { birth }\end{array}$} & $\begin{array}{l}\text { Remedies provided to relieve labour } \\
\text { pain } \\
\text { Support to speed up child birth }\end{array}$ \\
& Non-pharmacological remedies \\
\hline
\end{tabular}

TBAs also see labour pain as a necessity for a woman to have children, owing to the fact that labour pain precedes childbirth; the fetus in utero will initiate labour pain when ready: "... you see; it is only the baby that tells the mother when to push", and also: "The pain comes as a result of the pregnancy and... you know; we can't take the pain away totally but we can at least do something to help her cope with it until she delivers..." These perceptions were seen and held strongly, thereby influencing TBAs' attitudes towards how parturients are cared for.

\section{TBAs' experiences in pain management during labour}

This theme was formed by four (4) categories, namely: evaluation of parturients' labour pain, use of locally available remedies, psychological support and preferred setting for comfort in conducting delivery.

Evaluation of parturients' labour pain: TBAs assessed for presence of pain: "I appreciate the pains, because when the 'baby contracts' the mother feels the pain. Though some might be mild and some tense... it depends, but we need the pain to be there... we can only quicken the delivery," a TBA said.

However, through experience, most TBAs have observed that parturients want to endure the pain or start pushing when the cervix is not fully dilated; this is mostly seen in women with a low pain threshold.

"This labour pain... before I do anything I will check her first and if it's not yet time... I will know. But some women in labour will start pushing when it's not yet time... you see, it is only the baby that can tell the mother when to push" (TBA 1).

"You know the process of childbirth differs from one person to another; Woman-A will not be like Woman-B or Woman-C. Some labours are easier, whereas some are very difficult and take time" (TBA 13).

Care given to parturients by TBAs is mostly in the form of psychological support and encouragement. A TBA mentioned that "... the only thing we do here is to pet, pray for them and encourage them..."

Traditionally, most TBAs prefer parturients to come to their homes to deliver. Although in some selected cases, especially in an emergency, the TBA can go to the home of the parturient when called upon.

"They call me to anywhere... but I also deliver babies in my house..." (TBA 4).
"I use my house; I don't accept going to their houses... they should come here. I use my house, except when the person cannot move" (TBA 1, 4, 5, 7, 8, 12).

"Me, I don't have a house... I came from a poor and small family. So anywhere I am called to; I go. I only ask them to get everything I will need for the delivery; so they can provide it before I come" (TBA 11).

\section{Remedies provided to relieve labour pain and support to speed up child birth}

Non-pharmacological remedies and traditional herbal medicines were categories that emerged from the data. The non-pharmacological remedies used by the TBAs included: massage, walk from one end of the room to the other, deep breathing exercises, fetching water to fill a big drum, encouragement and petting, back rubbing, cold bath/shower, kneeling to eat, giving of special foods and drink, use of olive oil to make the outlet slippery, and use of a lateral position while lying down.

The TBAs did not mention any orthodox/pharmacological method as a means to relieve parturients' labour pain.

\section{Discussion}

\section{Theme 1: TBAs' beliefs and attitude to labour pain}

Naturalness of labour pain

Viewing labour pain as natural has definite implications for traditional midwifery practice and beliefs. These implications relate to how TBAs interpret the severity of labour pain, manage labour pain, use locally available remedies for labour pain relief, and respond to the reaction of parturients' behaviour to labour pain. TBAs' believe that labour pain is a natural phenomenon and that is how TBA perceives the nature of labour pain. The pain experienced by the woman in labour is caused by uterine contractions and the dilatation of the cervix, and in the late first stage and the second stage by the stretching of the vagina and the pelvic floor to accommodate the presenting part (Goldman et al., 2012; Leifer, 2005; Pillitteri, 2014).

A necessity for a woman to have children

Although labour pain is different from one parturient to another, parturients are mostly encouraged to bear the pain and its management. More so, the TBAs posited that labour pain is bearable and manageable. Although it can become unbearable for most parturients, it is still manageable: "The pain comes as a result of the pregnancy and...you know, you can't take the pain away totally but we can at least do something to help the woman cope with it until she delivers..." What participants expressed in this regard can be attributed to both the knowledge they have gained through attending to parturients and their personal experiences with parturients' labour pain management. As one TBA said, "... this labour pain is not easy at all..., and it is too much for one person to bear." She further expressed that, "that is why most people will not want to endure the pain, but for me, if there is a way to help them during labour, I use herbs". This is supported by Klomp et al. (2016), who stated that labour pain could be unbearable but manageable.

The perception of TBAs concerning the naturalness of labour pain is that it varies from parturient to parturient; in line with this, Newnham et al. (2017) stated that, labour experiences varies with each parturient: to some parturients the pain of labour is the most painful experience they had ever encountered. It is reiterated that these perceptions and accept- 
ance of pain attitudes could further influence TBAs' intervention approaches in practice (Vilakati, 2003).

\section{Theme 2: TBAs' lived experiences regarding pain management practices during labour}

This theme interprets the lived account of the TBAs experiences as it relates to labour pain in various perspectives in the following categories: Sacred Calling, Appreciating Pain, Examining Parturients, Some Are Masked, Pain Plus Urge to Push, Spiritual Association to Pain Labour, Unbearable, Confusion, Individual Uniqueness, Learning experience, and Benefits of the Learning Experience.

\section{Evaluation of labour pain}

TBAs view labour pain as a necessity in the onset of labour and therefore labour pain is appreciated. A TBA had this to say, "I appreciate the pains, because when the 'baby contracts' the mother feels the pain. Some might be mild and some tense... it depends, but we need the pain to be there..."

TBAs perform an abdominal examination with the hands to determine the position, presentation of the baby, and to determine the stage of labour and the level and process of labour.

TBAs' setting for comfort in conducting delivery

The birthing environment and the nature of the setting often dictate what is possible in managing labour pain. Most births take place in the homes of the TBA who is conducting the delivery because she is trusted by the people. In addition, midwives' presentation of themselves as being indigenous mothers and competent secures trust on the part of the parturient (Gallegos et al., 2017; Tasnim, 2010).

The majority of the TBAs in the study preferred using their homes, except in circumstances where the woman in labour cannot walk or in an emergency. The choice of using their homes is based on the comfort, familiarity and the ability to manipulate the birth environment for continuous labour support in order to achieve a satisfactory birth outcome. Evidence in literature indicates that an estimated 60 to $80 \%$ of all deliveries in the developing countries occur outside modern health care facilities - with a significant proportion of these attended to by TBAs (Ofili and Okojie, 2005). In Bangladesh, evidence revealed that the majority of births take place at home and $83 \%$ are conducted by TBAs. This is due to the fact that most mothers feel more at ease with their loved ones, and also, the TBA was either a relative or someone known to them and accustomed to their customs - and the woman would enjoy more control over her own childbirth (Tasnim, 2010).

\section{Theme 3: Remedies provided to relieve labour pain and support to fasten child birth}

The third theme that emerged from the data focuses on 'Locally Available Remedies' used by TBAs in Ogbia LGA to manage labour pain and the feedback of parturients concerning the remedies used.

It was mentioned earlier that in Bayelsa State, traditional obstetrical knowledge and practice has been passed down from generation to generation. TBAs in Ogbia LGA remain the gatekeepers of childbirth-related knowledge. Hence they are the first point of call and believed to be able to handle all pregnancy-related issues. Therefore, uses of herbal medicine are seen as the only source of remedy in some cases as reported by the participating TBAs in Ogbia LGA.

Non-pharmacological remedies

The study showed evidence of non-pharmacological remedies used as an intervention (subcategory) to the management of labour pain among parturients by TBAs. These emerged from the data as follows: massage, ambulation, special food/drinks, encouragement, hot-cold therapy, holy water, and olive oil.

The non-pharmacological methods avoid the use of drugs for pain relief in labour (Bamigboye and Holfmeyr, 2010). The non-pharmacological approach of pain management includes a wide variety of techniques to address not only the physical sensations to pain but also to prevent suffering by enhancing the psychological and spiritual components of care (Aduloju, 2013). The aim of using this approach goes beyond just relieving pain and is used to hasten child birth. Janssen et al. (2012) state that massage is commonly used to help tense muscles and to soothe and calm the individual. Touching another human being can communicate positive messages such as caring, concern, reassurance or love. Massage is the intentional and systemic manipulation of the soft tissues of the body to enhance health and healing. It is used during labour to enhance relaxation and reduce pain.

Massaging the abdomen is a therapeutic intervention used by TBAs in Ogbia LGA to manage pain in labour, because it is believed that it is only when they (the TBA) touch that they know what to do - and sometimes it may involve fondling in order to correct the wrong position of the baby in utero. This is a common practice, of which the TBAs are comfortable with the result. One particular respondentsaid: “... Though some 'doctors' (health care workers) say that if you massage the stomach during pregnancy, the baby will die... that is not true, because I have delivered up to 36 twins and there has been no problem; not even for one. I believe in massaging them during pregnancy and childbirth."

In line with this practice, Vilakati, (2003) reiterated that therapeutic massage can help to prepare a woman for the birthing process in several ways. Regular massage to the lower back, abdomen and inner thighs releases chronic tension, diminishing resistance during delivery. It encourages body awareness and a parasympathetic dominant state - thus reducing pain.

The pressure created by massage can help to counteract pain signals and promote relaxation in the early stage of labour. It is drug free, non-invasive and comforting and has no unpleasant effects on either the woman or the baby. However, massage during labour is a personal choice as some women cannot bear to be touched during a contraction, while others find that back rubbing helps (Vilakati, 2003).

Ambulation is an option in the early stages of labour, because it encourages contractions to become regular and stronger (Vilakati, 2003). Data collected showed that parturients are asked to move from point to point, because it helps the parturients to feel more relaxed, reduces fear and anxiety, and also enhances the progress of labour for quicker delivery.

\section{Traditional herbal remedies}

Traditional and herbal medicines refer to health practices, approaches, knowledge and beliefs incorporating plant, animal and mineral-based medicines, spiritual therapies, manual techniques and exercises, applied alone or in combination to treat, diagnose and prevent illnesses or to maintain wellbeing (Telles et al., 2014). The general indication for use of traditional medicine (roots and leaves) is based on their belief in it. A respondent stated, "I believe in our native roots and herbs... because if the place is too tight, and we give her our leaves or roots to chew, though it increases the pain she will deliver quickly." It also implies that for these roots to be administered, it must be a case that they perceived delays in the process of labour. As 


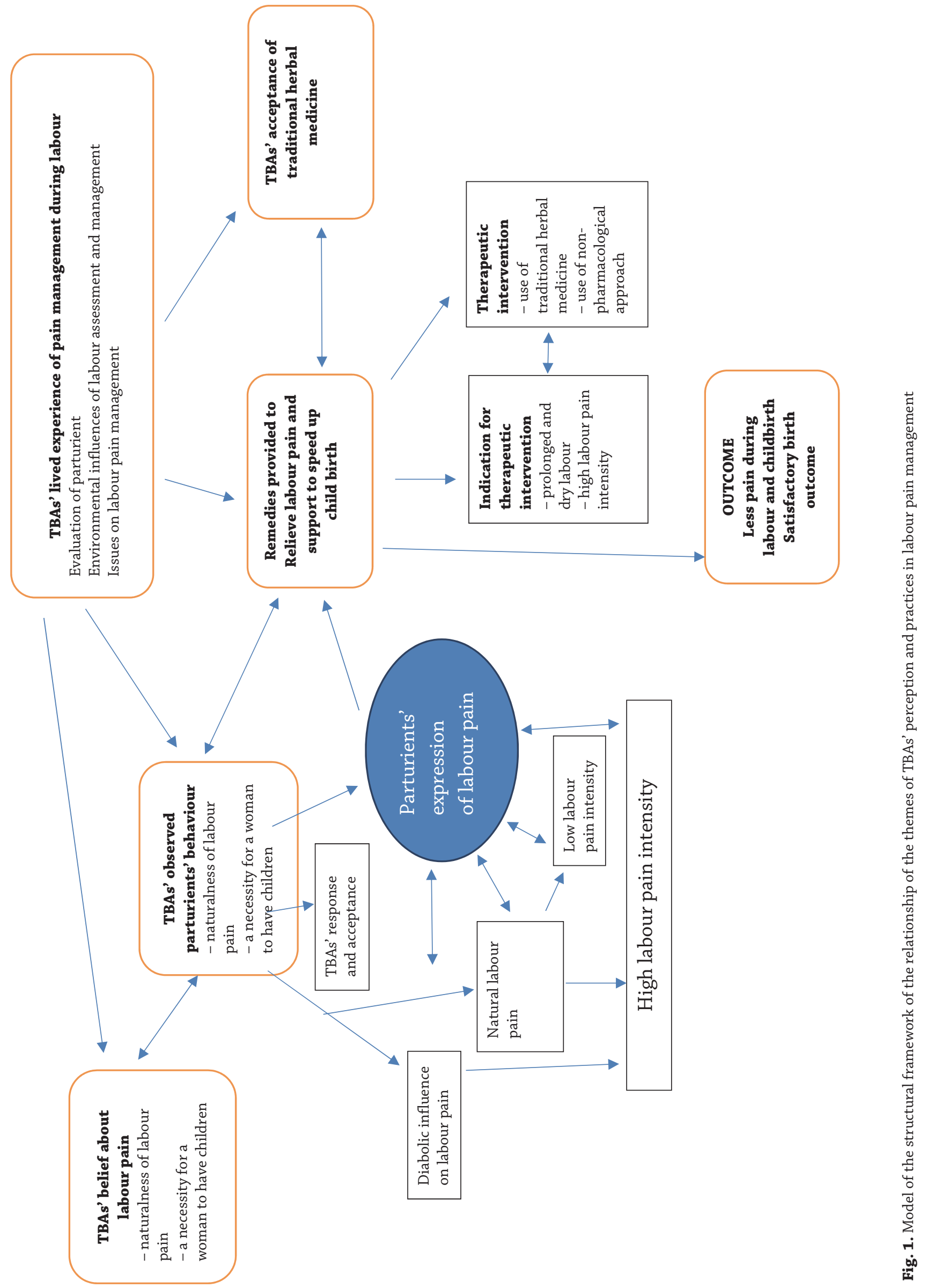


one respondent added: “... well, there are some local medicines that I give, but before I do this it must be a case of 'dry labour'."

\section{Model of structural framework}

TBAs' trado-cultural beliefs about labour pain forms the core of their experiences, as their experiences are born out of the beliefs they hold on to. TBAs view and believe that labour pain is a natural phenomenon and a necessity for a woman to have children; this perception interprets the approach adopted in the evaluation of parturients, providing a suitable environment for labour assessment and/or management, and how they handle issues of labour pain management during labour.

Evidence shows that experiences gathered by TBAs over time influences how parturients are managed during labour; that is, the way a TBA observes parturients' behaviour, whether labour pain should be managed or not, and what acceptable methods or local prepared remedy should be given to relieve labour pain and speed up the delivery of the child. Although TBA regards all behaviour expressed by parturients as a reaction to labour pain as normal, they also believe that most labour pain is influenced by diabolical means (expressed as very high pain intensity and very abnormal expressions of labour pain). Whether parturients' expression of labour pain is normal, abnormal (that is, high or no labour pain) or influenced by diabolical means, TBAs determine which approach would lead to a desired outcome: that is, to lessen pain during labour and childbirth and to see a satisfactory birth outcome (Fig. 1).

\section{Conclusions}

Labour pain which is characterised by regular, painful uterine contractions is a signal for the onset of labour. Although la- bour pain is a natural phenomenon, it differs from parturient to parturient. TBAs work with parturients by interpreting and managing labour pain; TBAs decide on which approach is best for labour pain management to lessen labour pain and to fasten the process of child birth using locally available remedies. Although not all TBAs see the use of traditional herbal medicine as appropriate, some TBAs seem to have developed and adapted to the use of a non-pharmacological approach to labour pain management for parturients.

\section{Recommendations}

Based on the findings of the study, the following recommendations were made; governmental and non-governmental agencies should further educate TBAs on care and how to respond to women experiencing labour pain individually, since every woman is individually unique and so are their behavioural responses to labour pain. The choice of pain relief methods, including pain relief medication should be discussed and confirmed with the woman concerned.

The government should also re-evaluate the policy that strengthens the Midwife Service Scheme in Nigeria to accommodate traditional birth attendants and to create effective guidelines for their training, practice and monitoring. By doing so, it creates an opportunity for the traditional and herbal medicines and other products and processes of labour pain management to be identified - and be exposed to scientific investigation and validation of efficacy.

\section{Conflict of interests}

The authors have no conflict of interests to disclose.

\section{Zkušenosti tradiční porodní asistentky s léčbou bolesti v péči o rodičky}

\section{Souhrn}

Cíl: Studie zkoumala vnímání zkušeností s ošetřováním bolesti při péči o rodičky v oblasti místní samosprávy Ogbia, Bayelsa, Nigeria.

Metodika: Studie přijala fenomenologicko-hermeneutický výzkumný návrh. S použitím účelové techniky vzorku a metody „sněhové koule“ bylo vybráno 13 porodních asistentek pro tuto studii. Sběr dat byl proveden s použitím hloubkového face-to-face rozhovoru.

Výsledky: Objevila se tři hlavní témata: (1) víra porodní asistentky a postoj k porodní bolesti, (2) zkušenosti porodní asistentky s řízením bolesti během porodu a (3) poskytované prostředky k úlevě od porodní bolesti a podpora zrychlení porodu.

Závěr: Bolest je přirozený jev, ale je vyjadřována každou rodičkou odlišně. Vnímání porodní bolesti porodní asistentkou je ukazatelem toho, jak porodní asistentka interpretuje a zvládá porodní bolest, kterou vyjadřují rodičky. Přístupy porodní asistentky k řízení bolesti jsou efektivnější s využitím místně dostupných léků ve formě bylin, jejichž cílem je urychlit porodní proces.

Klíčová slova: místní prostředky; řízení porodní bolesti; tradiční porodní asistentka; vnímání

\section{References}

1. Aduloju OP (2013). Pain perception among parturients at a University Teaching Hospital, South-Western Nigeria. Niger Med J. 54(4): 211-6. DOI: 10.4103/0300-1652.119597.

2. Aksoy H, Yucel B (2016). The relationship between expectation, experience and perception of labour pain: an observational study. Springerplus 2016 Oct 11; 5(1):1766. DOI: 10.1186/ s40064-016-3366-z.
3. Aziato L, Ohemeng HA, Omenyo CN (2016). Experiences and perceptions of Ghanaian midwives on labour pain and religious beliefs and practices influencing their care of women in labour. Reprod Health 13(1): 136. DOI: 10.1186/s12978-016-0252-7.

4. Bamigboye AA, Holfmeyr GJ (2010). Caesarean Section Wound Infiltration. S Afr Med J. 100(5): 313-317. DOI: 10.7196/ samj.3716.

5. Chaillet N, Belaid L, Crocheti C, Roy L, Gagne P, Moutquin JM, Rossignol M (2014). Birth Issues in Perinatal Care: Nonpharmacologic approaches for pain management during 
labor compared with usual care: a meta-analysis. Birth 41(2): 122-37. DOI: 10.1111/birt.12103.

6. Christiaens W, Verhaeghe M, Bracke P (2010). Pain acceptance and personal control in pain relief in two maternity care models: a cross-national comparison of Belgium and the Netherlands. BMC Health Serv Res 10: 268. DOI: 10.1186/1472-6963-10268.

7. Gallegos CA, Waters WF, Kuhlmann AS (2017). Discourse vs practice: are traditional practices and beliefs in pregnancy and childbirth included or excluded in the Ecuadorian health care system? Int Health 9(2): 105-111. DOI: 10.1093/inthealth/ ihw053.

8. Gama SG, Viellas EF, Torres JA, Bastos MH, Bruggemann OM, Theme Filha, et al. (2016). Labor and birth care by nurse with midwifery skills in Brazil. Reprod Health 13(Suppl. 3): 123. DOI: 10.1186/s12978-016-0236-7.

9. Goldman A, Hain R, Liben S (2012). Oxford Textbook of Palliative Care for Children. Oxford: Oxford University Press. DOI: $10.1093 / \mathrm{med} / 9780199595105.001 .0001$.

10. Halperin O, Sarid, O, Cwikel J (2014). A comparison of Israeli Jewish and Arab women's birth perceptions. Midwifery 30(7): 853-861. DOI: 10.1016/j.midw.2013.11.003.

11. Henderson J, Gao H, Redshaw M (2013). Experiencing maternity care: the care received and perceptions of women from different ethnic groups. BMC Pregnancy and Childbirth 13: 196. DOI: 10.1186/1471-2393-13-196.

12. Hodnett ED, Gates S, Hofmeyr GJ, Sakala C (2012). Continuous support for women during childbirth. Cochrane Database Syst Rev 10: CD003766. DOI: 10.1002/14651858.CD003766.pub4.

13. Janssen P, Shroff F, Jaspar P (2012). Massage therapy and labor outcomes: a randomized controlled trial.Int J Ther Massage Bodywork 5(4): 15-20. DOI: 10.3822/ijtmb.v5i4.164.

14. Jones L, Othman M, Dowswell T, Alfirevic Z, Gates S, Newburn M, et al. (2012). Pain management for women in labour: an overview of systematic reviews. Cochrane Database Syst Rev (3):CD009234. DOI: 10.1002/14651858.cd009234. pub2.

15. Klomp T, de Jonge A, Hutton EK, Hers S, Lagro-Janssen AL (2016). Perceptions of labour pain management of Dutch primary care midwives: a focus group study. BMC Pregnancy Childbirth 16: 6. DOI: 10.1186/s12884-015-0795-6.

16. Lawrence AL, Jimmy JA, Aluye-Benibo D, Igbans RO (2015a). Umbilical Cord Care Practices by Traditional Birth Attendants in Yenagoa, Nigeria. IOSR Journal of Nursing and Health Science (IOSR-JNHS), 4(2): 92-96. DOI: 10.9790/0837-04219296.

17. Lawrence AL, Jimmy JA, Okoye V, Abdulraheem A, Igbans RO, Uzere M (2015b). Birth Preparedness and Complication Readiness among Pregnant Women in Okpatu Community, Enugu State, Nigeria. International Journal of Innovation and Applied Studies 11(3): 644-649.

18. Leap N, Sandall J, Buckland S, Huber U (2010). Journey to confidence: women's experiences of pain in labour and relational continuity of care. J Midwifery Womens Health 55(3): 234-242. DOI: 10.1016/j.jmwh.2010.02.001.
19. Leifer $\mathrm{G}$ (2005). Maternity nursing: an introductory text. 9th ed. Philadelphia: W. B. Saunders.

20. Lincoln Y, Guba, E (1985). Naturalistic inquiry. New York: Sage.

21. Malheiros Dulfe PA, Alves VH, Rangel TSA, da Costa Vargens OM (2012). Labor and Birth: Knowledge and Humanized Practices. Texto Contexto - Enferm 21(2): 329-337. DOI: 10.1590/S0104-07072012000200010.

22. Newnham EC, McKellar LV, Pincombe JI (2017). Paradox of the institution: findings from a hospital labour ward ethnography. BMC Pregnancy Childbirth 17(1): 2. DOI: 10.1186/s12884-0161193-4.

23. Nilsson C, Lundgren I (2009). Women's lived experience of fear of childbirth. Midwifery 25(2): e1-9. DOI: 10.1016/j. midw.2007.01.017.

24. Ofili AN, Okojie OH (2005). Assessment of the Role of Traditional Birth Attendants in Maternal Health Care in Oredo Local Government Area, Edo State, Nigeria. Journal of Community Medicine and Primary Health Care 17(1): 55-60. DOI: $10.4314 / j \mathrm{cmphc.v17i1.32428.}$

25. Ogboli-Nwasor E, Adaji SE, Bature, SB, Shittu OS (2011). Pain relief in labor: a survey of awareness, attitude, and practice of health care providers in Zaria, Nigeria. J Pain Res 4: 227-232. DOI: $10.2147 / J P R . S 21085$.

26. Pillitteri A (2014). Maternal and child health nursing: care of the childbearing and childrearing family. 7th Ed. Philadelphia: Lippincott Williams \& Wilkins.

27. Pirdel M, Pirdel L (2009). Perceived environmental stressors and pain perception during labor among primiparous and multiparous women. J Reprod Infertil 10(3): 217-223.

28. Polit DF, Beck CT (2012). Nursing research: generating and assessing evidence for nursing practice. Ninth Edition. Philadelphia: Wolters Kluwer Health/Lippincott Williams \& Wilkins.

29. Saravanan S, Johnson H, Turrell G, Fraser J (2011). Social Roles and Birthing Practices of Traditional Birth Attendants in India with reference to other Developing Countries. Asian Journal of Women's Studies 15(4): 57-89. DOI: 10.1080/12259276.2009.11666078.

30. Tasnim S (2010). Perception about Pain Relief during Normal Labour Among Health Care Providers Conducting Delivery. Medicine Today 22(1): 20-21. DOI: 10.3329/medtoday. v22i1.5600.

31. Telles S, Pathak S, Singh N, Balkrishna A (2014). Research on Traditional Medicine: What Has Been Done, the Difficulties, and Possible Solutions. Evidence-Based Complementary and Alternative Medicine,June 2014. DOI: 10.1155/2014/495635

32. Vilakati CZ (2003). Mozambican Women's Experiences of Labour Pain. A dissertation submitted to the Department of Health Studies, University of South Africa.

33. Whitburn LY, Jones, LE, Davey MA, Small R (2014). Women's experiences of labour pain and the role of the mind: an exploratory study. Midwifery 30(9): 1029-1035. DOI: 10.1016/j.midw.2014.04.005. 